
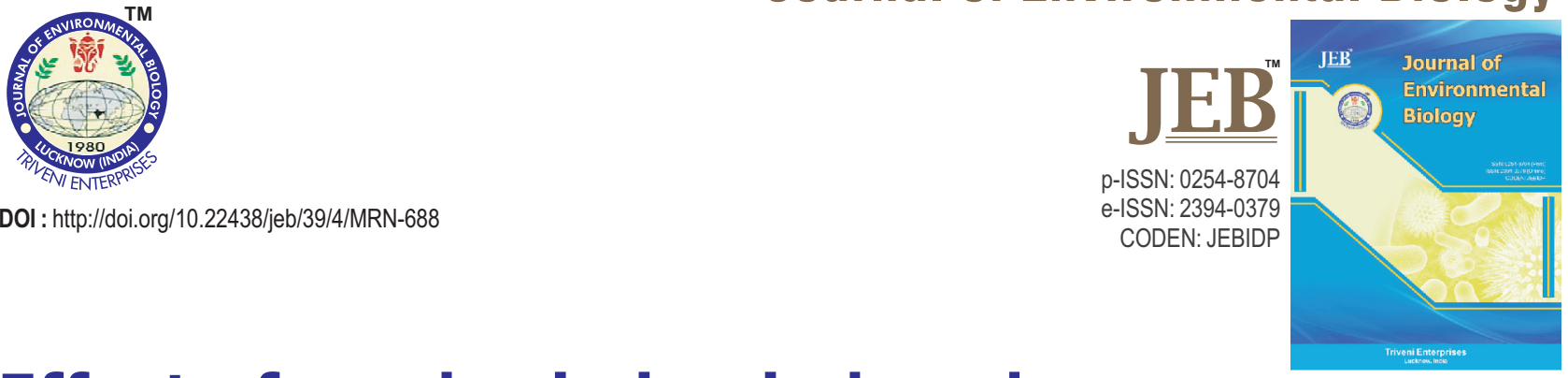

\title{
Effect of seed priming induced metabolic changes on germination and field emergence of chickpea
}

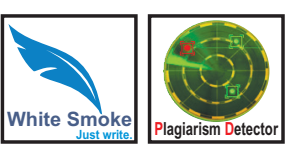

Authors Info

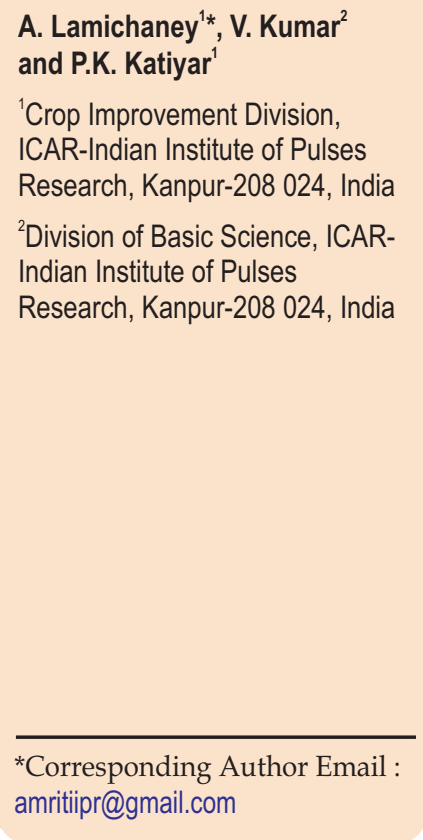

Key words

Chickpea

Field emergence

Germination

Priming

Protein synthesis

\section{Publication Info}

Paper received : 06.07.2017

Revised received: 19.12 .2017

Accepted : 16.01 .2018

\section{Abstract}

Aim : Seed priming improves vigour, however, different priming agents may vary in their effectiveness. Therefore, main aim of this study was to decipher the physiological mechanism of vigour improvement following seed priming using different agent.

Methodology : Chickpea cultivar Kripa was primed with different concentration of poly ethylene glycol, mannitol, salicylic acid, gibberellic acid and water for varying duration. Dry unprimed seed was used as control. De novo protein synthesis, sugar content, electrical conductivity of seed leachate, germination percent, time to $50 \%$ germination, uniformity of germination, germination energy, field emergence, hundred seed weight, seed yield were determined to understand the physiological basis of priming.

Results : Priming reduced time to $50 \%$ germination, mean germination time and improved germination energy, final germination, field emergence and seed yield over control. Overall, the favourable effect of seed priming were related to de novo protein synthesis, an improved membrane repair (revealed by low ion leakage) and germination substrates (increased sugar content) for vigorous and earlier production of seedlings.

Interpretation : Of the treatments, seeds primed with water for $17 \mathrm{hrs}$ and PEG -0.5 / -1.0 Mpa for $24 \mathrm{hrs}$ were most effective in enhancing field emergence and seed yield of chickpea and can be therefore recommended for increasing productivity in chickpea.

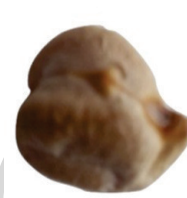

Unprimed seed
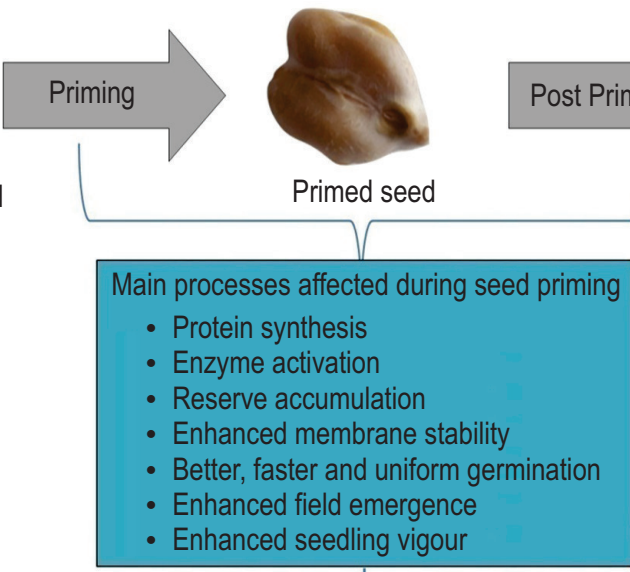

Primed seed
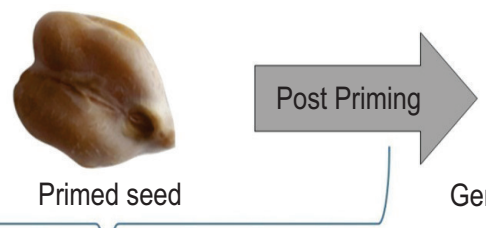

Germinated primed seed

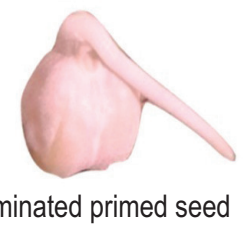

Increased yield 


\section{Introduction}

High, rapid and uniform emergence is crucial for achieving an optimal crop stand and better productivity, since slow rate of germination exposes seedling to unfavourable environmental condition affecting their vigour (Osburn and Schroth, 1989). Germination begins with the imbibition of water by dry seed and completes with protrusion of radicle through seed coat (Bewley et al., 2013), within these period the seed repairs all the deformities and prepares itself to produce a normal and healthy seedling. Seed vigor is a complex trait which is defined as the sum of those properties that determines the activity and performance of seed lots of acceptable germination in a wide range of environments (ISTA, 2011). Increased production of quality seed has become a need of an hour to meet the current demand of crop production. Seed priming is one of the approaches to enhance seed vigour (Farooq et al., 2006; Catusse et al., 2011). Seed priming method includes hydro-priming, osmopriming, nutrient-priming, halo-priming, bio-priming, hormonalpriming, matrix-priming, drum-priming, magneto-priming and thermo-priming (Kubala et al., 2015). Primed seeds are reported to performed better even under adverse field conditions like salinity (Kim et al., 2006; Srivastava et al., 2010a, b), temperature extremes (Wahid and Shabbir, 2005; Nawaz et al., 2011), drought (Kaur et al., 2005; Elkoca et al., 2007). Thus, seed priming cannot be considered only as a mere germination acceleration process but as a stress mitigating process, since it prepares seed to perform better even in different biotic and abiotic stresses prevailing during seedling emergence and early seedling growth (Jisha et al., 2013). The uniform, rapid and better germination of primed seed occurs due to changes in morphology, physiology, biochemistry and molecular level. Among them, alterations in metabolite levels are important events during seed invigoration or priming. Transcriptomic and proteomic studies have revealed up regulation or down regulation of a number of genes and proteins during seed priming (Gallardo et al., 2001; Kubala, 2015; Szymon et al., 2015). Advanced germination metabolism, increased activity of antioxidants, decreased level of malondialdehyde, altered ratio of saturated and unsaturated fatty acids and increased level of hydrolyzing enzymes are some of the changes associated with seed priming (Bailly et al., 2000; Walters et al., 2005; Yacoubi et al., 2011).

Chickpea (Cicer arietinum L.) is an important legume and is a vital source of protein to majority of vegetarian population. India is the leading chickpea producing country with about $68 \%$ share in global chickpea production (FAO, 2014). Generally, two market types of chickpea, kabuli (non-pigmented and large seeded) and desi (pigmented and small seeded) are well reported. Seed coat colour is imparted by the presence of tannin in seed coat, which is known to have antifungal, antimicrobial properties and acts as a chemical defensive trait for plant or seed (Zhang et al., 2016). In legumes, seed vigour is associated with seed coat pigmentation, pigmented seeds being more vigorous than unpigmented one (Kantar et al., 1996; Peksen, 2007). Similarly, kabuli chickpea are less vigorous than desi type. Kabuli chickpea recorded poor field emergence as compared to desi type even though their laboratory germination was high (Lamichaney et al., 2016, 2017). As per an estimate, the use of quality seed, keeping other inputs constant, could enhanced the yield by more than $20 \%$. Therefore, use of high quality seed is vital to produce healthy and vigorous seedlings that lead to better crop stand and higher yield under a wide range of environment. Reports showing benefits of priming on vigour enhancement are numerous, but those highlighting the biochemical and physiological mechanism of such changes, especially in kabuli chickpea are scarce. Each treatment varies in their effectiveness, therefore the effect of metabolic changes due to different seed priming agents are specific. With respect to this hypothesis, the physiological changes caused by the most effective priming agent (in terms of improved vigour) and their relationships to laboratory germination and field establishment was evaluated.

\section{Materials and Methods}

Seed materials : The experiments were conducted at ICARIndian Institute of Pulses Research, Kanpur. Seeds of chickpea cv. Kripa were used as an experimental material. Kripa is an extra large seeded kabuli chickpea having a hundred seed weight of $\sim 55 \mathrm{~g}$.

Seed priming treatment : There were 9 treatments with 4 seed pre-treatment reagents, namely, Polyethylene glycol (-0.5, -1.0, 1.5 MPa), Mannitol (2, $4 \%)$, Salicylic acid (50 nm), Gibberellic acid (50 ppm), hydro-priming and unprimed seed as control. Surface sterilization of seeds was carried out by immersing completely in $0.1 \%$ mercuric chloride for 2 min followed by washing with distill water. These surface sterilized seeds were placed in between two layer of filter paper pre moistened with the respective priming agents. Thereafter, the Petri-plates were kept at dark in incubator set to a temperature of $20^{\circ} \mathrm{C}$ for varying time depending upon the treatment. For PEG and mannitol, the priming duration was $24 \mathrm{hrs}$ and for rest of the treatments the priming duration was $17 \mathrm{hrs}$. In any case, there was no evident cracking of seed coat or protrusion of radicle at the end of the priming period. After the respective priming duration, the seeds were thoroughly washed 2-3 times using distill water to remove osmoticum or chemicals from seed coat, followed by drying at ambient laboratory temperature for 3-4 days till the seeds had dried to their original moisture content. Dry unprimed seeds were used as control.

Laboratory germination studies : Total of 150 seeds (three replicates of 50 seeds each) were kept for germination in an incubator at $20^{\circ} \mathrm{C}$ in rolled germination towels (ISTA, 2011). Germination was observed three to four times a day. Seed was considered germinated when the radical had attained a length of $2 \mathrm{~mm}$. After seven days, the final percentage germination, actual time to $50 \%$ emergence $\left(t_{50}\right)$ and uniformity of germination $\left(t_{90 / 10}\right)$ were calculated. Germination energy represents the ratio of germinated seeds over total seeds on $4^{\text {th }}$ day of experiment. Daily germination performance of primed and unprimed seeds were 
interpreted by germinator model of Joosen (2010) by the equation given by El-Kassaby et al. (2008).

Field experiment : The field evaluation of primed and unprimed control was done in New Research Campus, ICAR-Indian Institute of Pulses Research, Kanpur for two consecutive rabi season (2015-16 and 2016-17). The crop was sown in a plot of size $4 \mathrm{~m}$ length and $2 \mathrm{~m}$ width in Randomized Complete Block Design in three replicate. Each replication (plot) had four rows with 25 seeds placed in each row (total of 100 seeds per plot). Field emergence data was recorded after 21 days of sowing. At harvest, ten plants were randomly selected per replication to measure plant height $(\mathrm{cm})$, number of pods and seeds per plant. The seeds obtained from each plot represents seed yield per plot.

Priming-induced metabolic changes : To extract total protein for SDS PAGE analysis, seed material $(200 \mathrm{mg})$ was ground in a pre-chilled mortar pestle in chilled extraction buffer $(0.1 \mathrm{M}$ Tris $(\mathrm{pH}$ 7.5), 1\% Triton $X-100)$. The amount of total proteins was quantified using Lowry's method (Lowry et al., 1951). For fractionation of proteins, $20 \mathrm{~g}$ of protein was mixed in appropriate volume of $4 \mathrm{X}$ loading buffer and resolved on $12 \%$ gel and electrophoresed at $80 \mathrm{~V}$. The gel was stained in a staining solution (0.1\% Coomassie brilliant blue R-250, 50\% methanol and 10\% glacial acetic acid) for overnight. After washing several times in destaining solution ( $40 \%$ methanol and $10 \%$ glacial acetic acid), the gel was scanned, and molecular mass of the expressed peptides was ascertained by comparing with standard protein markers.

Electrical conductivity of seed leachate was estimated according to ISTA (2011). Total sugar contents were estimated by anthrone regent (Yoshida et al., 1976). Reducing sugar was estimated according to Miller (1959) and differences between total sugar and reducing sugar gave the content of non reducing sugar.

Statistical analysis : SPSS 16.0 software package was used for statistical analysis. Duncan Multiple Range Test (DMRT) was performed at $p=0.05$ to test the significance of differences, which were indicated by alphabets on data sets.

\section{Results and Discussion}

All seed treatments significantly improved laboratory germination percent, germination energy and subsequently reduced mean germination time and time to achieve 50\% germination $\left(t_{50}\right)$ over control. Also, the time interval between $10 \%$ and $90 \%$ of the seeds to germinate or uniformity of germination $\left(t_{9010}\right)$ was better in seeds primed by different chemicals/agents. Data on germination attributes of seeds revealed significant $(P=0.05)$ differences among priming treatments (Table 1). Although all treatments were effective in curtailing the time to achieve $50 \%$ germination, hydro-priming, salicylic acid and $2 \%$ mannitol were the most effective. Similar increase in germination speed and synchrony of chickpea (Elkoca et al., 2007), maize (Tian et al., 2014), rice (Basra et al., 2005), sunflower (Wahid et al., 2008) have been reported through seed priming in previous studies. Rapid and synchronized germination after priming may be the result of dormancy breakdown. Increased metabolic activities and replication in root tips might have resulted into early and synchronized germination after priming (Basra et al., 2002). Mean germination time was highest $(29.55 \mathrm{hr})$ in control, but it was lowest (11.95 hr) in hydro-primed seeds. Seed priming greatly improved germination energy (potential of seed to germinate vigorously) as compared to control, being highest in PEG -1.5 Mpa, hydro-priming, salicylic acid and 2\% mannitol followed by gibberelic acid and $4 \%$ mannitol. Likewise, laboratory germination percent was improved by all the priming treatments but most of all by PEG -1.5 Mpa and hydro-priming (Table 1, Fig. 1). Seed germination stage and seedling stage are most critical stages in crop cycle which affects crop yield both qualitatively and quantitatively. Seed germination comprises of three phases, it starts with water imbibition by dry seeds, followed by a lag phase (germination stricto sensu) and ends with radical protrusion through seed coat. Seed priming prolongs phase II that is lag phase, that allows seed to go through various pre-germination changes but prevents radical protrusion. Results indicated that seed priming significantly decreased mean germination time and time taken to achieve $50 \%$ germination. However, seed primimg increased germination energy as well as final germination value in kabuli chickpea CV. Kripa. The favourable effect of seed

Table 1: Effect of priming treatments on germination and related attributes of chickpea

\begin{tabular}{llllll}
\hline Treatments & $\mathrm{T}_{50}(\mathrm{hr})$ & $\mathrm{T}_{90 / 10}(\mathrm{hr})$ & MGT $(\mathrm{hr})$ & Germination energy & Germ (\%) \\
\hline Control & $32.65^{\mathrm{a}}$ & $24.03^{\mathrm{a}}$ & $29.55^{\mathrm{a}}$ & $62.5^{\mathrm{d}}$ & $72.50^{\mathrm{c}}$ \\
PEG -0.5 Mpa (24 hr) & $28.85^{\mathrm{b}}$ & $20.77^{\mathrm{ab}}$ & $25.75^{\mathrm{b}}$ & $65.0^{\text {cd }}$ & $90.00^{\mathrm{ab}}$ \\
PEG -1.0 Mpa (24 hr) & $26.20^{\mathrm{bc}}$ & $20.50^{\mathrm{ab}}$ & $26.40^{\mathrm{ab}}$ & $67.5^{\mathrm{bcd}}$ & $90.00^{\mathrm{ab}}$ \\
PEG -1.5 Mpa (24 hr) & $22.25^{\mathrm{d}}$ & $20.77^{\mathrm{ab}}$ & $21.90^{\mathrm{c}}$ & $92.5^{\mathrm{a}}$ & $95.00^{\mathrm{a}}$ \\
Mannitol 2\% (24 hr) & $12.70^{\mathrm{f}}$ & $17.55^{\mathrm{ab}}$ & $13.70^{\mathrm{de}}$ & $87.5^{\mathrm{a}}$ & $87.50^{\mathrm{ab}}$ \\
Mannitol 4\% (24 hr) & $23.30^{\mathrm{cd}}$ & $15.85^{\mathrm{ab}}$ & $23.00^{\mathrm{bc}}$ & $72.5^{\mathrm{bc}}$ & $85.00^{\mathrm{b}}$ \\
Salicylic acid (17 hr) & $11.30^{\mathrm{f}}$ & $19.90^{\mathrm{ab}}$ & $13.00^{\mathrm{de}}$ & $85.0^{\mathrm{a}}$ & $87.50^{\mathrm{ab}}$ \\
Gibberellic acid (17 hr) & $20.42^{\mathrm{d}}$ & $17.77^{\mathrm{ab}}$ & $20.16^{\mathrm{c}}$ & $73.5^{\mathrm{b}}$ & $86.33^{\mathrm{b}}$ \\
Hydropriming (17 hr) & $10.15^{\mathrm{f}}$ & $17.45^{\mathrm{ab}}$ & $11.95^{\mathrm{e}}$ & $85.0^{\mathrm{a}}$ & $95.00^{\mathrm{a}}$ \\
\hline
\end{tabular}

Mean followed by similar alphabets indicates non-significant differences between the values at 0.05 level of significance 
Table 2 : Effect of priming treatments on biochemical changes in chickpea seeds

\begin{tabular}{|c|c|c|c|}
\hline Treatments & $\begin{array}{l}\text { Total sugar } \\
\text { (mg g } \mathrm{m}^{-1} \text { fresh seed) }\end{array}$ & $\begin{array}{l}\text { Reducing sugar } \\
\text { (mg g } \text { fresh seed) }^{-1} \text { ) }\end{array}$ & $\begin{array}{l}\text { Non reducing sugar } \\
\text { (mg g }{ }^{-1} \text { fresh seed) }\end{array}$ \\
\hline Control & $6.66^{f}$ & $3.61^{\mathrm{e}}$ & $3.05^{\mathrm{a}}$ \\
\hline PEG -0.5 Mpa & $8.77^{\circ}$ & $6.65^{b}$ & $2.12^{b}$ \\
\hline PEG-1.0 Mpa & $11.16^{\mathrm{a}}$ & $8.22^{\mathrm{a}}$ & $2.94^{\mathrm{a}}$ \\
\hline PEG -1.5 Mpa & $7.60^{\mathrm{de}}$ & $6.28^{b}$ & $1.32^{\circ}$ \\
\hline Mannitol 2\% & $7.60^{\mathrm{de}}$ & $6.32^{b}$ & $1.28^{\circ}$ \\
\hline Mannitol 4\% & $7.52^{\mathrm{e}}$ & $4.61^{\mathrm{d}}$ & $2.91^{a}$ \\
\hline Salicylic acid & $7.97^{\mathrm{d}}$ & $6.41^{\mathrm{b}}$ & $1.55^{\mathrm{c}}$ \\
\hline Gibberellic acid & $9.44^{\mathrm{b}}$ & $6.55^{\mathrm{b}}$ & $2.89^{\mathrm{a}}$ \\
\hline Hydropriming & $7.79^{\text {de }}$ & $5.41^{\circ}$ & $2.37^{\mathrm{b}}$ \\
\hline
\end{tabular}

Mean followed by similar alphabets indicates non-significant differences between the values at 0.05 level of significance

Table 3 : Effect of priming treatment on emergence and yield attributes of chickpea

\begin{tabular}{|c|c|c|c|c|c|c|}
\hline Treatments & $\begin{array}{l}\text { Field } \\
\text { emergence (\%) }\end{array}$ & $\begin{array}{l}\text { Plant } \\
\text { height }(\mathrm{cm})\end{array}$ & $\begin{array}{l}\text { No. of } \\
\text { pods per plant }\end{array}$ & $\begin{array}{l}\text { No. of } \\
\text { seeds per plant }\end{array}$ & $\begin{array}{l}100 \text {-seed } \\
\text { weight }(\mathrm{g})\end{array}$ & $\begin{array}{l}\text { Yield } \\
\left(\mathrm{kg} \mathrm{ha}^{-1}\right)\end{array}$ \\
\hline Control & $47.83^{b}$ & $40.18^{a}$ & $17.73^{\mathrm{a}}$ & $16.89^{a}$ & $47.74^{\text {bc }}$ & $507.28^{c}$ \\
\hline PEG (-0.5 Mpa) & $68.17^{\mathrm{a}}$ & $40.10^{a}$ & $17.94^{a}$ & $17.55^{\mathrm{a}}$ & $53.79^{a}$ & $733.09^{a}$ \\
\hline PEG (-1.0 Mpa) & $67.33^{\mathrm{a}}$ & $40.53^{a}$ & $17.73^{\mathrm{a}}$ & $16.97^{\mathrm{a}}$ & $47.05^{\mathrm{bc}}$ & $713.00^{\mathrm{ab}}$ \\
\hline PEG (-1.5 Mpa) & $62.33^{\mathrm{ab}}$ & $39.11^{a}$ & $18.27^{\mathrm{a}}$ & $17.80^{\mathrm{a}}$ & $46.12^{c}$ & $610.81^{\text {abc }}$ \\
\hline Mannitol (2\%) & $67.67^{\mathrm{a}}$ & $38.42^{a}$ & $19.47^{\mathrm{a}}$ & $19.63^{\mathrm{a}}$ & $53.13^{a}$ & $607.18^{\mathrm{abc}}$ \\
\hline Mannitol (4\%) & $63.33^{\mathrm{ab}}$ & $36.94^{\mathrm{a}}$ & $16.15^{\mathrm{a}}$ & $16.90^{\mathrm{a}}$ & $54.56^{\mathrm{a}}$ & $552.58^{\mathrm{bc}}$ \\
\hline $\mathrm{GA}(50 \mathrm{ppm})$ & $59.50^{\mathrm{ab}}$ & $40.24^{a}$ & $16.34^{a}$ & $14.23^{\mathrm{a}}$ & $53.23^{\mathrm{a}}$ & $486.19^{c}$ \\
\hline $\mathrm{SA}(50 \mathrm{~nm})$ & $60.33^{\mathrm{ab}}$ & $40.36^{a}$ & $16.43^{\mathrm{a}}$ & $15.20^{\mathrm{a}}$ & $52.63^{\mathrm{a}}$ & $579.39^{\mathrm{abc}}$ \\
\hline Hydropriming & $68.67^{\mathrm{a}}$ & $41.15^{\mathrm{a}}$ & $17.94^{\mathrm{a}}$ & $16.80^{\mathrm{a}}$ & $49.52^{b}$ & $717.98^{\mathrm{a}}$ \\
\hline
\end{tabular}

Mean followed by similar alphabets indicates non-significant differences between the values at 0.05 level of significance

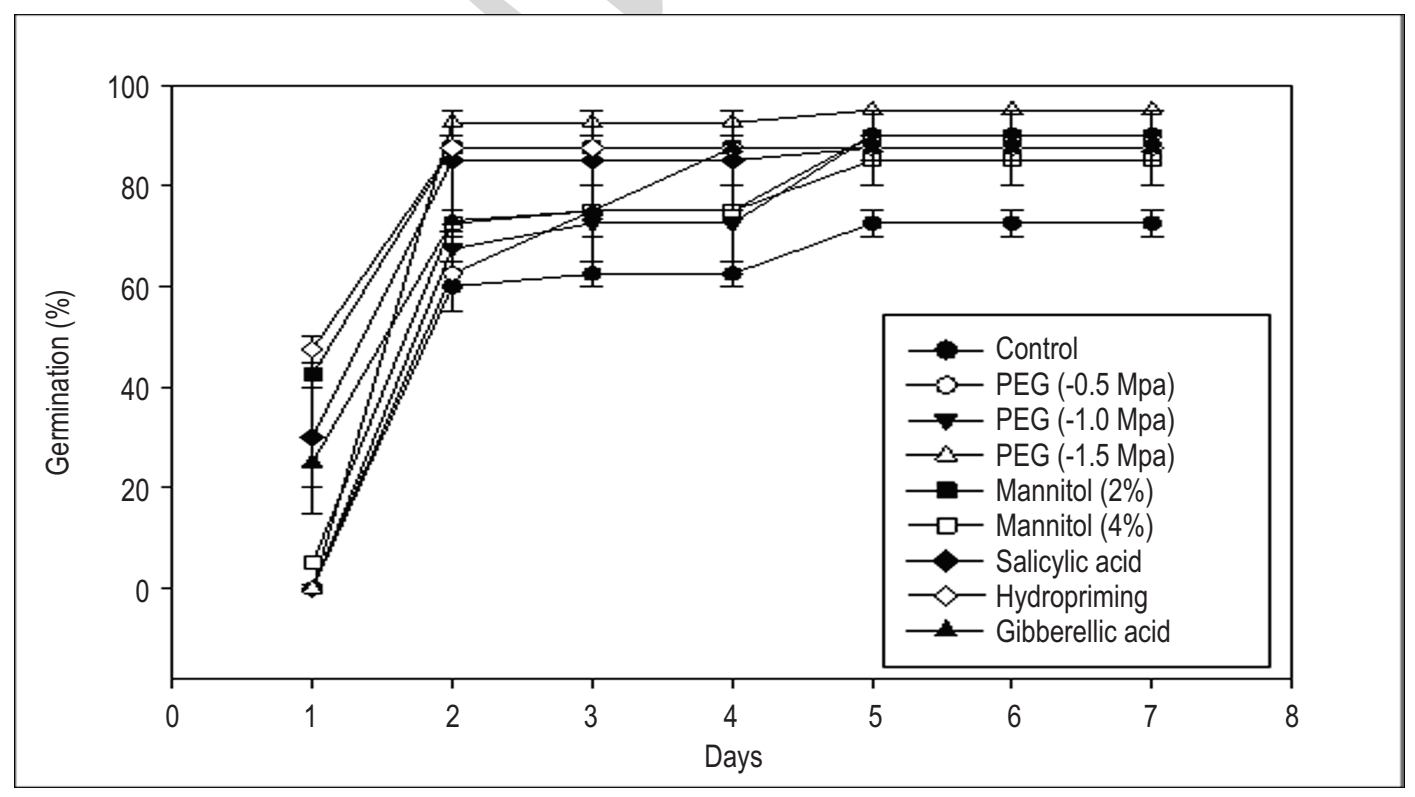

Fig. 1 : Effect of the priming treatments on germination curve of chickpea seeds. Bars are \pm S.E. 


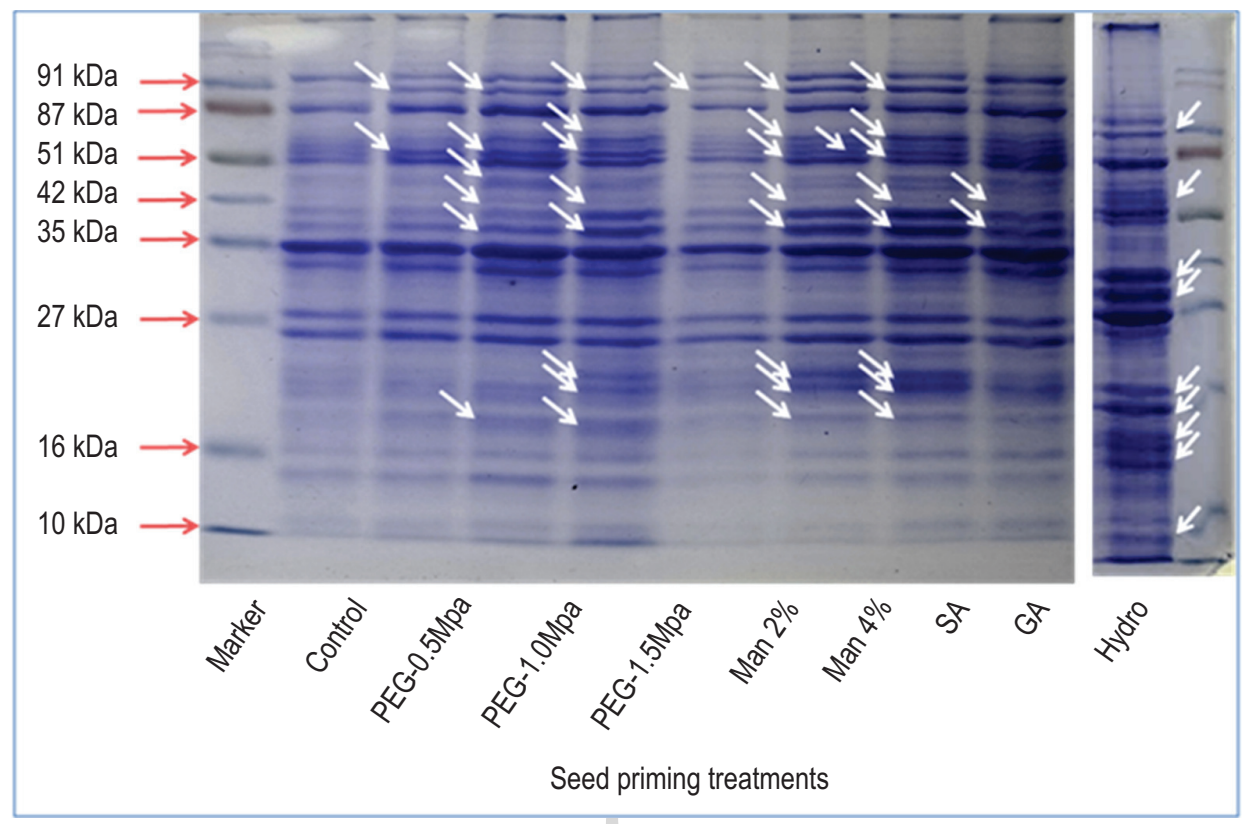

Fig. 2 : Electrophoretic pattern and molecular weight of expressed protein following priming in chickpea

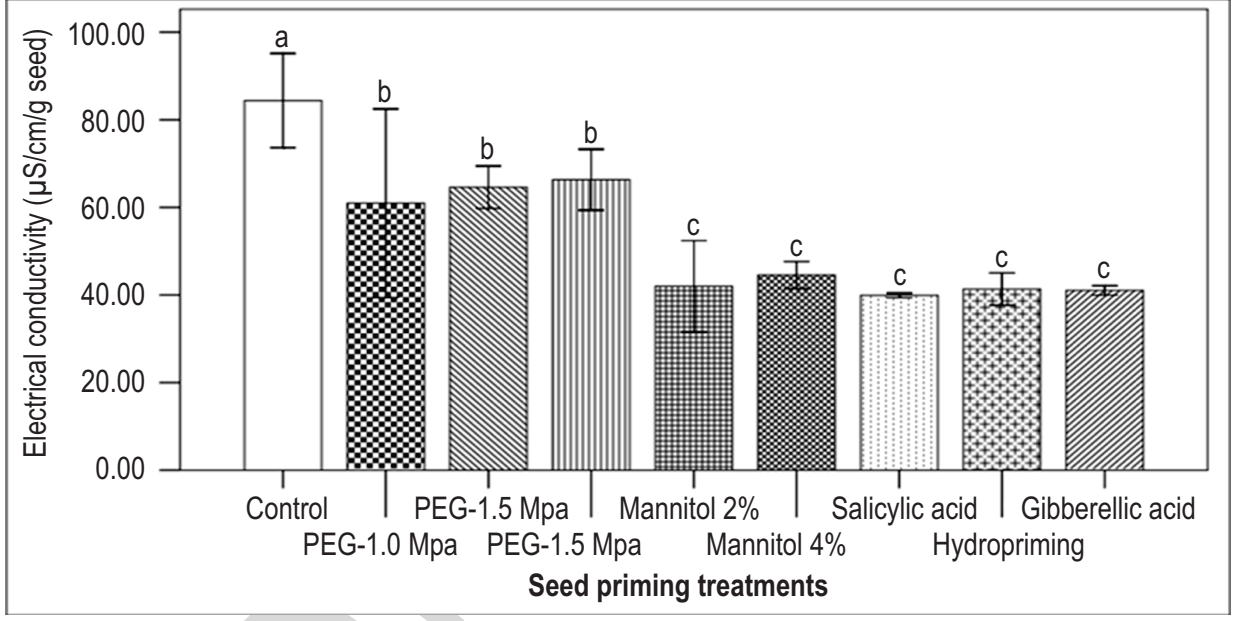

Fig. 3 : Effect of priming treatments on electrical conductivity of chickpea seed leachate. Bars with same alphabets were not significantly different $(\mathrm{p}=0.05)$.

priming observed may be attributed to repair mechanisms, enhanced protein synthesis, enhanced respiratory activity of seeds, breaking of dormancy, imbibition and enzymes activation.

Plant height, number of pods and seeds per plant were not affected by seed priming. However, seed priming significantly increased field emergence. Field emergence was lowest $(47.83 \%)$ in control, whereas PEG - $0.5 \mathrm{Mpa}$, PEG $-1.0 \mathrm{Mpa}, 2 \%$ mannitol and hydro-priming recorded highest (67-69\%). Similarly, seed priming improved hundred seed weight over control, except for PEG -1.0 and PEG -1.5 Mpa. Osmo-priming with PEG -0.5 Mpa recorded highest yield followed by PEG -1.0 Mpa and hydro-priming. Kaur et al. (2002), have reported improved performance of osmo-primed and hydro-primed chickpea crop under field with an increase in yield up to 39 to $64 \%$. Favourable effect of seed priming treatments in terms of increasing field emergence may be attributed to de novo protein synthesis, membrane repair and better accumulation of reserves. These findings are in agreement with Tian et al. (2014); Harris et al. $(2000,2002)$, who reported better performance following pre-soaking and drying. The metabolic processes which are induced in seed by priming persist even after drying (Asgedom and Becker, 2001). Thus, upon sowing, dried primed seed as soon as 
imbibes water revives the seed metabolism, resulting into faster and synchronous emergence.

SDS PAGE profiling indicated the differential expression of proteins with seed priming. Notably, protein of $89 \mathrm{kDa}$ was expressed in all the priming treatments except for control. Similarly, proteins of 20 and $25 \mathrm{kDa}$ were expressed in seeds primed with PEG, mannitol, salicylic acid and hydro-priming, while a $12 \mathrm{kDa}$ protein was induced only by hydro-priming. In general, the band intensity as well as the number of proteins induced by seed priming increased over control (Fig. 2). Kubala et al. (2015), found positive association of improved germination in PEG-osmoprimed brassica seeds with protein synthesis and reported higher expression of proteins involved in water transport, modification in cell wall, cell division and management of oxidative stress after PEG-osmopriming. Proteins like tubulin, sub unit of 12S-seed storage protein, heat shock proteins, phoshoenolpyruvate carboxykinase, catalase increased upon hydropriming and/or PEG-osmopriming in Arabidopsis seed, all of which has very important role in germination or plant growth (Gallardo et al., 2001). The sugar content of the seed (total, reducing and non-reducing) was significantly influenced by various seed priming treatments. Highest contents of total and reducing sugars were recorded in the seeds primed with PEG 1.5 Mpa for $24 \mathrm{hrs}$ (Table 2). Seed priming resulted in significantly higher contents of total as well as reducing sugars but reduced the content of non-reducing sugars over control. Our findings corroborated with the findings of Basra et al. (2005). They reported that the increase in alpha amylase activity following priming resulted into increased content of total and reducing sugar as alpha amylase hydrolyzed non reducing sugar to reducing and starch to sugar. Rapid, uniform and better germination of primed seed over control suggested that the effect of starch hydrolysis were not lost during re-drying process. Regarding electrical conductivity of seed leachate, unprimed control seeds recorded highest value and seeds primed by salicylic acid recorded lowest. However, electrical conductivity of seed leachate in salicylic acid did not differ with that of Mannitol (2\%), Mannitol (4\%), Gibberellic acid and hydro-priming (Fig. 3). It is evident that priming process leads to repair mechanism of membrane, enhancing its stability as primed seeds recorded lower electrical conductivity than unprimed control.

Seeds primed with water for $17 \mathrm{hrs}$ and PEG $-0.5 /-1.0$ Mpa for 24 hrs resulted into higher field emergence and seed yield, therefore, these treatments may be recommended for increasing productivity of chickpea. Enhanced germination, field emergence and seed yield of hydro and osmo-primed seeds were associated with de novo proteins synthesis, repair mechanisms and greater availability of substrate.

\section{Acknowledgment}

The authors are highly thankful to the supporting staff of ICAR-IIPR for technical help during the experiment.

\section{References}

Asgedom, $H$. and M. Becker: Effects of seed priming with nutrient solutions on germination, seedling growth and weed competitiveness of cereals in Eritrea. In: Proceedings Deutscher Tropentag 2001, University of Bonn and ATSAF, Magrraf Publishers Press, Weickersheim, p. 282 (2001).

Bailly, C., A. Benamar, F. Corbineau and D. Come:Antioxidant systems in sunflower (Helianthus annuus L.) seeds as affected by priming. Seed Sci. Res., 10, 35-42 (2000).

Basra, S.M.A., M. Farooq, R. Tabassam and N. Ahmad: Physiological and biochemical aspects of pre-sowing seed treatments in fine rice (Oryza sativa L.). Seed Sci. Technol., 33, 623-628 (2005).

Basra, S.M.A., M.N. Zia., T. Mehmood., I. Afza and A. Khaliq: Comparision of different invigoration techniques in wheat (Triticum aestivum L.) seeds. Pak. J. Arid Agri., 5, 11-16 (2002).

Bewley, J.D., K.J. Bradford, H.W.M. Hilhorst and H. Nonogaki: Seeds : Physiology of development, germination and dormancy. $3^{\text {rd }}$ Edn., Springer, New York (2013).

Catusse, J., J. Meinhard, C. Job, J.M. Strub, U. Fischer, E. Pestsova, P. Westhoff, A. Van Dorsselaer and D. Job: Proteomics reveals potential biomarkers of seed vigor in sugarbeet. Proteomics, 11, 1569-1580 (2011).

El-Kassaby, Y.A., I. Moss, D. Kolotelo and M. Stoehr: Seed germination : Mathematical representation and parameters extraction. Forest Sci., 54, 220-227 (2008).

Elkoca, E., K. Haliloglu, A. Esitken and S. Ercisli : Hydro and osmopriming improve chickpea germination. Acta Agric. Scand. Sect. B Soil Plant Sci., 57, 193-200 (2007).

Farooq, M., S.M.A. Basra and A. Wahid: Priming of field sown rice seed enhances germination, seedling established, allometry and yield. Plant Growth Regul., 49, 285-294 (2006).

Food and Agriculture Organization : FAOSTAT Database. Food and agriculture organization of the united nations, Rome (2014).

Gallardo, K., C. Job, S.P.C. Groot, M. Puype, H. Demo, J. Vandekerhove and D. Job: Proteomic analysis of Arabidopsis seed germination and priming. Plant Physiol., 126, 835-848(2001).

Harris, D., R.S. Tripathi and A. Joshi: On-farm seed priming to improve crop establishment and yield in dry direct-seeded rice. In: Direct seeding: research strategies and opportunities. (Eds.: S. Pandey, M. Mortimer, L. Wade, T.P. Tuong, K. Lopes and B. Hardy) IRRI, Manila, Philippines, pp. 231-240 (2002).

Harris, D., R.S. Tripathi and A. Joshi: On-farm seed priming to improve crop establishment and yield in dry direct-seeded rice. Proc. Inter. Workshop on Dry-Seeded Rice Tech., Bangkok, Thailand, pp. 2528 (2000).

International Seed Testing Association: International Rules for Seed Testing. Seed Sci. Tech., 13, 44 (2011).

Jisha, K.C., K. Vijayakumari and J.T. Puthur: Seed priming for abiotic stress tolerance : An overview. Acta Physiol. Plant., 35, 1381-1396 (2013).

Joosen, R.V.L., J. Kodde, L.A.J. Willems, W. Ligterink, H. Linus and H.W.M. Hilhorst: GERMINATOR: A software package for highthroughput scoring and curve fitting of Arabidopsis seed germination. The Plant J., 62, 148-159 (2010).

Kantar, F., C. Pilbeam and P. Hebblethwaite: Effect of tannin content of faba bean (Vicia faba) seed on seed vigour, germination and field emergence. Ann. App. Bio., 128, 85-93 (1996).

Kaur, S., A.K. Gupta and N. Kaur: Effect of osmo and hydro-priming of chickpea seeds on crop performance in the field. Int. Chickpea Pigeonpea Newsl., 9, 15-17 (2002).

Kaur, S., A.K. Gupta and N. Kaur: Seed priming increases crop yield 
possibly by modulating enzymes of sucrose metabolism in chickpea. J. Agron. Crop Sci., 19, $81-87$ (2005).

Kim, S.K., T.K. Son, S.Y. Park, I.J. Lee, BzH. Lee, H.Y. Kim and S.C. Lee: Influences of gibberellin and auxin on endogenous plant hormone and starch mobilization during rice seed germination under salt stress. J. Environ. Bio., 27, 181-186 (2006).

Kubala, S., M. Garnczarska, L. Wojtyla, R. Rucinska-Sobkowiak, S. Kubala and M. Garnczarska: Deciphering priming-induced improvement of rapeseed (Brassica napus L.) germination through an integrated transcriptomic and proteomic approach. Plant Sci., 231, 94-113 (2015).

Lamichaney, A., P.K. Katiyar, S. Kudekallu and N. Sarangapany: Relationship among some seed characters, laboratory germination and field emergence in chickpea (Cicer arietinum L.) genotypes differing in testa colour. J. Food Leg., 29, 29-32 (2016).

Lamichaney, A., S. Kudekallu, U. Kamble, N. Sarangapany, P.K. Katiyar and A. Bohra: Differences in seed vigour traits between desi (pigmented) and kabuli (non-pigmented) ecotypes of chickpea (Cicer arietinum L.) and its association with field emergence. J. Environ. Bio., 38, 735-742 (2017).

Lowry, O.H., N.J. Rosebrough, A.L. Farr and R.J. Randall: Protein measurement with the Folin phenol reagent. J. Biol. Chem., 193, 265-275(1951).

Miller, G.I.: Use of dinitro-salicylic acid reagent for the determination of reducing sugars. Analytical Chem., 31, 426-428 (1959).

Nawaz, A., M. Amjad, M.A. Pervez and I. Afzal: Effect of halopriming on germination and seedling vigor of tomato. Afr. J. Agric. Res., 6, 3551-3559 (2011).

Osburn, R.M. and M.N. Schroth: Effect of osmopriming sugar beet deed on exudation and subsequent damping-off caused by Pythium ultimum. Phytopathology, 78, 1246-1250 (1989).

Peksen, E.: Relationships among electrical conductivity of seed leakage, germination, field emergence percentage and some seed traits in faba bean (Vicia faba). Asian J. Chem., 19, 31783184 (2007).

Srivastava, A.K., P. Suprasanna, S. Srivastava and S.F. D'Souza:
Thiourea mediated regulation in the expression profile of aquaporins and its impact on water homeostasis under salinity stress in Brassica juncea roots. Plant Sci., 178, 517-522 (2010b).

Srivastava, A.K., V.H. Lokhande, V.Y. Patade, P. Suprasanna, R. Sjahril and S.F. D'Souza: Comparative evaluation of hydro, chemo and hormonal priming methods for imparting salt and PEG stress tolerance in Indian mustard (Brassica juncea L.). Acta Physiol. Plant., 32, 1135-1144 (2010a).

Szymon, K., M. Garnczarskaa, Ł. Wojtylaa, A. Clippeb, A. Kosmalac, A. Zmienkod, S. Luttse and M. Quinete: Deciphering priming-induced improvement of rapeseed (Brassica napus L.) germination through an integrated transcriptomic and proteomic approach. Plant. Sci., 231, 94-113 (2015).

Tian, Y., B. Guan, D. Zhou, J. Yu, G. Li and Y. Lou: Responses of seed germination, seedling growth, and seed yield traits to seed pretreatment in maize (Zea mays L.). The Sci. World J., 2014, 1-8 (2014).

Wahid, A. and A. Shabbir: Induction of heat stress tolerance in barley seedlings by pre-sowing seed treatment with glycine betaine. Plant Growth Regul., 46, 133-141 (2005).

Wahid, A., N. Asma, M.A.B. Shahzad, G. Sadia and M. Farooq: Priminginduced metabolic changes in sunflower (Helianthus annuus) achenes improve germination and seedling growth. Bot. Studies, 49, 343-350 (2008).

Walters, C., P. Landre, L. Hill, F. Corbineau and C. Bailly : Organization of lipid reserves in cotyledons of primed and aged sunflower seeds. Planta, 222, 397-407 (2005).

Yacoubi, R., C. Job, M. Belghazi, W. Chaibi and D. Job: Toward characterizing seed vigor in alfalfa through proteomic analysis of germination and priming. J. Proteome Res., 10, 3891-3903 (2011).

Yoshida, S., D.A. Forno, H.H. Cock and K.A. Gomez: Laboratory manual for physiological studies of rice. IRRI, Los Banos (1976).

Zhang, Z., Z. Wang, G. Chang, X. Yi, J. Lu, Z. Xiao, H. Zhang, L. Cao, F. Wang, H. Li and C. Yan: Trade-off between seed defensive traits and impacts on interaction patterns between seeds and rodents in forest ecosystems. Plant Ecol., 217, 253-265 (2016). 